\title{
Vertical growth of mini watermelon according to the training height and plant density
}

\author{
Rafael Campagnol' ${ }^{1}$ Simone da C Mello; ${ }^{1}$ José Carlos Barbosa ${ }^{2}$ \\ 'USP-ESALQ, Depto. Prod. Vegetal, C. Postal 9, 13418-900 Piracicaba-SP; rcampagnol@usp.br; scmello@esalq.usp.br; ${ }^{2}$ UNESP-FCAV, \\ Depto. Ciências Exatas, Rodov. Prof. Paulo Donato Castellane s/n, 14884-900 Jaboticabal-SP; jcbarbosa@fcav.unesp.br.
}

\begin{abstract}
The watermelon is traditionally cultivated horizontally on the ground. The cultivars of small fruits (1 to $3 \mathrm{~kg}$ ), which reach better market prices, are also being grown in a greenhouse, where the plants are trained upward on vertical supports, with branches pruning and fruits thinning. These practices make possible an increase of the plant density, fruit quality and yield compared to the traditional growth system. The aim of this experiment was to evaluate the influence of three training heights $(1.7,2.2$ and $2.7 \mathrm{~m})$ and two planting densities ( 3.17 and 4.76 plants $\mathrm{m}^{-2}$ ) over the productive and qualitative characteristics of mini watermelon "Smile" cultivated in greenhouse. The pruning was done at 43, 55 and 66 days after transplanting (DAT), when the plant height reached 1.7, 2.2 and $2.7 \mathrm{~m}$, respectively. The dry mass of branches, petioles, leaves and total were affected by the training height, where the highest values were obtained by the plants pruned at 2.2 and $2.7 \mathrm{~m}$. Leaf area, specific leaf area and leaf area index were not affected by the height of the plants. The training height of $2.7 \mathrm{~m}$ raised the total yield, however, marketable yield, average fruit mass and all the quality characteristics did not differ significantly from those obtained by the training height of $2.2 \mathrm{~m}$. Regarding to plant density, the best option was 4.76 plants $\mathrm{m}^{-2}$, due to the increasing of marketable yield in $37.4 \%$ without reducing the average weight of fruits.
\end{abstract}

Keywords: Citrullus lanatus, growth density, plant spacing, training systems.

\section{RESUMO}

Cultivo vertical de mini melancia em função da altura de condução e densidade de plantas

A melancia é uma espécie tradicionalmente conduzida em campo no sistema rasteiro. As cultivares de frutos pequenos (1 a $3 \mathrm{~kg}$ ), que adquirem melhores preços de mercado, vêm sendo cultivadas também em ambiente protegido, onde são conduzidas no sistema vertical, com poda de ramos e raleio de frutos. Essas práticas possibilitam aumentar o adensamento das plantas, a qualidade e a produtividade de frutos em comparação ao sistema rasteiro. Objetivou-se com este trabalho avaliar a influência de três alturas de condução $(1,7$; $2,2$ e $2,7 \mathrm{~m})$ e duas densidades de plantas $\left(3,17\right.$ e 4,76 plantas $\left.\mathrm{m}^{-2}\right)$ sobre as características produtivas e qualitativas da mini melancia "Smile" cultivada em ambiente protegido. A poda da haste principal foi realizada aos 43, 55 e 66 dias após o transplante (DAT) para as alturas de condução de 1,7;2,2 e 2,7 m, respectivamente. A massa seca dos ramos, dos pecíolos, das folhas e total foram afetados pela altura de condução, cujos maiores valores foram obtidos para as plantas conduzidas a 2,2 e 2,7 m de altura. A área foliar, a área foliar específica e o índice de área foliar não foram influenciados pela altura de condução das plantas. A altura de condução de 2,7 m elevou a produtividade total. Entretanto, a produtividade comercial, a massa média dos frutos e todas as características qualitativas não foram significativamente diferentes das obtidos pela altura de poda de 2,2 m. Em relação à densidade de plantas, a melhor opção foi a de 4,76 plantas $\mathrm{m}^{-2}$, pois elevou a produtividade comercial em $37,4 \%$ sem reduzir a massa média dos frutos.

Palavras-chave: Citrullus lanatus, densidade de cultivo, espaçamento entre plantas, sistemas de condução.

\section{(Recebido para publicação em 11 de outubro de 2011; aceito em 9 de setembro de 2012) (Received on October 11, 2011; accepted on September 9, 2012)}

$\mathrm{T}_{\mathrm{i}}^{\mathrm{h}}$ he watermelon (Citrullus lanatus) is the most cultivated cucurbitacea species in the world. In 2010, Brazil was the fourth largest world producer (1.87 million tonnes) and had the fifth largest harvested area (9040 thousand hectares). However, Brazil is in the $46^{\text {th }}$ position for productivity (20.69 $\left.\mathrm{t} \mathrm{ha}^{-1}\right), 26 \%$ below the world average (28.15 t ha-1) (FAO 2012) that reflects the low investment and technological level involved in the cultivation of this vegetable.

In Brazil, watermelon is traditionally cultivated in the field in the horizontal system with production of large size fruit (6 to $15 \mathrm{~kg}$ ). More recently, cultivation of cultivars that produce 1.5 to $3.0 \mathrm{~kg}$ fruits, called "mini" or "icebox" fruits has increased among producers, who search for different products with greater aggregated value and cater to consumers with ever smaller families who demand quality products.
Mini watermelons can be cultivated in the field, in the horizontal system, or in a protected environment, in the vertical system. The latter provides better conditions for plant development by protecting against rainfall and low temperatures, enhancing chemical application efficiency and water and fertilizer use (Papadopoulos, 1994), factors that contribute to increase in productivity and fruit quality. Furthermore, as the watermelon is a 
tropical climate crop and sensitive to low temperatures (Almeida, 2006), its cultivation in a protected environment permits fruit production out of season, a period when better prices are obtained on the market.

However, to train the plants in the vertical system, knowledge of plant pruning and fruit thinning practices is fundamental to obtain higher productivity and quality in the fruit. These cropping techniques create conditions to maximize production by establishing the ideal number of fruits per plant, the best cover of the area by leaves and plant uniformity, promoting the source-drain balance according to the productive needs (Papadopoulos, 1994). In addition, training makes chemical application easier, improves plant ventilation and solar radiation distribution in the canopy and enables increase in plant density, generating a greater number of fruits per area (Martins et al., 1999).

Plant density management is essential to obtain a greater number of fruits of commercial standard, because while plant adensing can lead to increase in productivity it can also result in decrease in the mean fruit mass (Sanders et al., 1999; Kultur et al., 2001; Goreta et al., 2005). Increased plant density usually, for most species, raises biomass productivity to a certain limit, after which productivity remains equal or decreases (Willey \& Heath, 1969).

According to Watanabe et al. (2003), increase in plant density in vertical watermelon cropping decreases the leaf area of the upper third and middle of the plants and reduces solar radiation interception by the leaves of the lower portion, resulting in decrease in its photosynthesis efficiency and consequently the quantity of photoassimilates directed to the fruit. However, although it decreases fruit size, reducing between plant spacing raises productivity. This productive plasticity, obtained by managing the number of plants per area, allows a greater quantity of fruit to be produced of the size the consumer market demands and that obtain higher prices.

Thus the objective of the present study was to assess the effect of training height and plant density on watermelon cultivated in a protected environment on the productive and qualitative characteristics.

\section{MATERIAL AND METHODS}

The experiment was carried out from August 12 to November 25, 2008, in the experimental area of the Plant Production Department at the "Luiz de Queiroz" Agricultural College ESALQ/USP, in the municipality of Piracicaba, São Paulo state, Brazil. The climate is the Cwa type by the Köppen classification, that is, wet subtropical with three drier months (June, July and August), summer rains, dry winter, temperature in the hottest months over $22^{\circ} \mathrm{C}$ and in the coolest month lower than $18^{\circ} \mathrm{C}$.

The cropping soil was identified as a Eutrophic Red Nitossol, that presented the following results in the chemical analysis: organic matter (potassium dichromate $)=45 \mathrm{mg} \mathrm{dm}^{-3} ; \mathrm{P}($ resin $)=$ $374 \mathrm{mg} \mathrm{dm}^{-3} ; \mathrm{K}($ resin $)=18.7$ mmolc $\mathrm{dm}^{-3} ; \mathrm{Ca}($ resin $)=106.8$ mmolc dm $^{-3} ; \mathrm{Mg}$ $($ resin $)=43.2$ mmolc dm $^{-3} ; \mathrm{pH}\left(\mathrm{CaCl}_{2}\right)=$ 6.4; $\mathrm{S}=108 \mathrm{mg} \mathrm{dm}^{-3} ; \mathrm{CTC}=192.7$ mmolc $\mathrm{dm}^{-3} ; \mathrm{V} \%=92 ; \mathrm{B}($ hot water $)=$ $0.93 \mathrm{mg} \mathrm{dm}^{-3}$.

An arch-type greenhouse was used, $6.40 \mathrm{~m}$ wide, $30 \mathrm{~m}$ long, the sides closed with anti-aphid screens and the structure covered with $150 \mu \mathrm{m}$ thick polyethylene film (anti UV). The height of the central part was $4.6 \mathrm{~m}$ and the wall height was $3.5 \mathrm{~m}$. During the cultivation period, the means of the maximum, minimum and mean temperatures and relative air humidity recorded by a digital datalogger were $35.1^{\circ} \mathrm{C}, 15.2^{\circ} \mathrm{C}, 23.1^{\circ} \mathrm{C}$ and $63.3 \%$, respectively.

The Smile hybrid watermelon cultivar was used, characterized by fruits with $1.5-2.5 \mathrm{~kg}$ mass and a 35 40 day productive cycle after anthesis. The plants were fertirrigated daily with nutritive solutions appropriate for each development phase of the plants. Phases I, II and III corresponded to the periods from transplant to thesis, from anthesis to the start of fruit development and from the start of fruit development to harvest, respectively. The quantity of fertilizers used in the I, II and III phases were, respectively, $180.5 ; 201.5$ and $500.0 \mathrm{mg}$ $\mathrm{L}^{-1}$ potassium nitrate $(13 \% \mathrm{~N}$ and $44 \%$ $\left.\mathrm{K}_{2} \mathrm{O}\right) ; 380.0 ; 426.0$ and $300.0 \mathrm{mg} \mathrm{L}^{-1}$ calcium nitrate $(15 \% \mathrm{~N}$ and $20 \% \mathrm{Ca})$; 50.0; 100.0 and $0.0 \mathrm{mg} \mathrm{L}^{-1}$ ammonium nitrate $(33 \% \mathrm{~N}) ; 230.0 ; 257.0$ and 80.0 $\mathrm{mg} \mathrm{L}^{-1}$ monoammonium phosphate $\left(10 \% \mathrm{~N}\right.$ and $\left.52 \% \mathrm{P}_{2} \mathrm{O}_{5}\right) ; 190.0 ; 210.0$ and $140.0 \mathrm{mg} \mathrm{L}^{-1}$ magnesium sulfate $(9.5 \%$ $\mathrm{Mg}$ and $12 \% \mathrm{~S}) ; 192.0 ; 192.0381 .0 \mathrm{mg}$ $\mathrm{L}^{-1}$ potassium sulfate $\left(50 \% \mathrm{~K}_{2} \mathrm{O}\right.$ and $18 \% \mathrm{~S})$; and $10.0 ; 15.0$ and $15.0 \mathrm{mg} \mathrm{L}^{-1}$ "Rexolin" (1.5\% B, 0.5\% Cu, 3.4\% Fe, $3.2 \% \mathrm{Mn}, 0.1 \% \mathrm{Mo}, 4.2 \% \mathrm{Zn}, 12 \% \mathrm{~K}$, $1.2 \% \mathrm{Mg} 1.5 \% \mathrm{~S}$ ).

The irrigation system consisted of self-compensating drippers, with 1.0 $\mathrm{L} \mathrm{h}^{-1}$ flow. Each plant had a drip point. The nutritive solution volumes applied were calculated based on the readings of tensiometers placed in three locations in the greenhouse, close to the plants, installed at 15 and $30 \mathrm{~cm}$ depth, with a $20 \mathrm{kPa}$ water detention limit in the soil, as reported by Marouelli (2008).

The treatments resulted in a $3 \times 2$ factorial arrangement, consisting of three main stem training heights (1.70; 2.20 and $2.70 \mathrm{~m}$ ) and two plant densities (4.76 and 3.17 plants $\mathrm{m}^{-2}$ ). A randomized block experimental design was used with four replications. The plants were distributed in the area in double rows, with $50 \mathrm{~cm}$ between rows and $90 \mathrm{~cm}$ between double rows. The between plant spacing on the row was $30 \mathrm{~cm}$ for greater plant density and $45 \mathrm{~cm}$ for the lower plant density, that resulted in plots with 30 and 20 plants, respectively. The 16 central plants were assessed in each plot.

The seedlings were produced on 200-cell styrofoam trays filled with coconut fiber substrate. Forty days after sowing (DAS) they were transplanted to beds covered with black plastic according to the plant distribution in each treatment.

The plants were trained vertically with plastic strings tied on steel wires raised over the cropping rows 1.5 and $2.9 \mathrm{~m}$ height. The plants were trained after the emission of the fourth definitive leaf by wrapping the plastic strings around the stems. The first three secondary branches were removed as soon as they appeared and the rest were cut after the third leaf. The central stem 
was pruned when the plants reached the heights defined for each treatment. This occurred at 43, 55 and 66 days after seedlings transplant (DAT) for the 1.7. 2.2 and $2.7 \mathrm{~m}$ training heights, respectively.

The plants were pollinated by hand between 8 a.m. and 10 a.m. every day, starting on the $36^{\text {th }}$ DAT, until all the emerged female flowers between the $8^{\text {th }}$ and $14^{\text {th }}$ internode on the main stem were pollinated. When the fixing of the fruits in the desired position was guaranteed, the others were eliminated, leaving only one fruit per plant supported by nylon nets (bags) tied to the horizontal wires located $1.5 \mathrm{~m}$ above soil level over the planting row.

To determine the ideal harvest point, the fruits from the border were harvested when they reached the maximum size, the tendril next to the peduncle was dry, the skin lost shine and changed texture and the fruit when hit made a deep, hollow sound (Almeida, 2006). When the pulp of these fruit presented soluble solids content equal or greater than $10^{\circ}$ Brix the fruits were harvested with the same characteristics. The harvest started at 94 DAT.

The following characteristics were assessed: the branch dry matter (BDM), petiole dry matter (PDM), leaf dry matter (LDM) and total dry matter (TDM); leaf area (LA) specific leaf area (SLA) and leaf area index (LAI); mean fruit matter (MFM); total yield (TY), commercial productivity (CY), mean fruit length (MFL), mean fruit diameter (MFD) and fruit shape index (FSI); pulp firmness (PF), skin thickness (ST), soluble solid content (SS) ascorbic acid content (AA) titratable acidity (TA) and fruit $\mathrm{SS} / \mathrm{TA}$ ratio.

The dry matter $(\mathrm{g})$ of the different plant parts was determined by collecting four plants per plot in the harvest period. Each plant was separated into the leaf blade, petioles and stems that were dried in a forced air circulation chamber at $65^{\circ} \mathrm{C}$ until constant mass was obtained. The TDM consisted of the sum of the masses of the different plant parts.

The leaf blades, before drying, were used to determine the LA $\left(\mathrm{cm}^{2}\right.$ plant $\left.^{-1}\right)$ using an area integrator (LI-COR, model LI 300). The SLA ( $\left.\mathrm{cm}^{2} \mathrm{~g}^{-1}\right)$ was calculated by the ratio between the leaf area and the leaf blade dry matter. The LAI $\left(\mathrm{cm}^{2} \mathrm{~cm}^{-2}\right)$ was determined by the ratio between the leaf area and the area that each plant occupied in the soil, according to the plant density.

Twelve fruits were assessed per plot to determine the variables MFM (kg), TY (t ha-1), CY ( $\left.\mathrm{t} \mathrm{ha}^{-1}\right)$, MFL and MFD (cm). The commercial yield was estimated from the difference between the total yield and the yield of fruits smaller than $1.0 \mathrm{~kg}$. The shape index was calculated by the ratio between the fruit length and diameter.

After weighing and measuring, four fruits per plant were selected randomly to determine the PF $(\mathrm{N}), \mathrm{EC}(\mathrm{cm}), \mathrm{SS}$ ( ${ }^{\circ}$ Brix), AA (mg $100 \mathrm{~g}^{-1}$ ), TA (\% citric acid) and the SS/TA ratio of the fruit.

The PF was determined from the mean of three readings by a manual penetrometer (QA supplies, model FT 011) with an $8.0 \mathrm{~mm}$ needle in the central region of fruits cut longitudinally. The ST was based on the means of two measurements taken in the equatorial region of the fruit using a manual pachymeter. The SS was determined by direct reading in homogenized pulp solution of each fruit using a refractometer (Atago, model PR-32 $\alpha$ ).

To determine the AA, $10 \mathrm{~g}$ pulp were diluted in $90 \mathrm{~mL} 1 \%$ oxalic acid and titered with 2.6-dichlorophenolindophenol solution (Carvalho et al., 1990). The TA was carried out using 10 $\mathrm{g}$ homogenized pulp diluted in $90 \mathrm{~mL}$ distilled water. The titering was done with sodium hydroxide $(0.05 \mathrm{~N})$ until the solution reached $\mathrm{pH}$ equal to 8.1. by a digital $\mathrm{pH}$ meter (Tecnal, model Tec-3MP), according to methodology described by Carvalho et al. (1990). The SS/TA was calculated by the ratio between the soluble solid content and titratable acidity to assess the state of the fruit ripeness and flavor (Chitarra \& Chitarra, 2005).

For the statistical analysis the Shapiro Wilk test was carried out for all the variables studied to verify whether the data followed normal distribution (if $p$-valor $>0.05$ ) and the Bartlett test was used to verify the homogeneity of the variance. Later the results were submitted to analysis of variance and the means compared by the Tukey test at 5\% probability, using the AgroEstat statistical program.

\section{RESULTS AND DISCUSSION}

Dry matter of branches, petioles, leaves and total dry matter; leaf area, specific leaf area and leaf area index There was no significant interaction for the training heights and plant density for BDM, PDM, LDM, TDM, LA, SLA and LAI (Table 1).

The training heights of the plants influenced BDM, PDM, LDM and TDM and the greatest values were obtained for the plants pruned at 2.2 and $2.7 \mathrm{~m}$ (Table 1), but the plant training heights did not influence LA, SLA or LAI. This fact probably occurred because in the plants pruned at $1.7 \mathrm{~m}$ the development of the secondary ramifications were greater because stimulus (cutting the tip bud) occurred 12 and 23 days before the plants pruned at 2.2 and $2.7 \mathrm{~m}$, respectively.

Queiroga et al. (2008) however, assessed the productive and quality characteristics of watermelon in function of the number of fruit and leaves per plant and observed linear increases in the leaf area according to the number of leaves per plant, that is, due to the increase in the training height of the plants. However, these increases were less pronounced when two fruits were fixed per plant. When the plants were pruned with the smallest number of leaves (16 leaves), the plants trained with two fruits presented larger leaf area compared to the plants with one fruit. According to the author this showed that, on these plants, the greater leaf expansion occurred in an attempt to adjust their leaf area to the greater demand of the drain by photoassimilates because of the greater number of fruits maintained and thus compensating the lower ratio between source (leaves) and drain (fruits).

Plant density did not significantly alter the BDM, PDM, LDM or TDM (Table 1), corroborating the results obtained by Duarte \& Peil (2010) for dry matter of the vegetative fraction, leaves and stem of watermelon cultivated vertically in a protected environment 
and with Ramos et al. (2009) for canopy fresh matter of six watermelon cultivars, one of them the Smile hybrid.

The results presented for vegetative part dry matter showed that the $50 \%$ increase in the number of plants per area was not sufficient to restrict the vegetative growth. For Peil \& LopézGalvéz (2002) however, the 27.7\% (from 1.8 to 2.3 plants $\mathrm{m}^{-2}$ ) increase in plant density reduced the dry matter of trained cucumber plants. Heuvelink (1995) reported that the increase in plant density in trained tomato from 1.6 to 3.1 plants $\mathrm{m}^{-2}(93.7 \%$ increase in the number of plants per area) reduced their growth and consequently their total dry matter. According to the author, the reduction in vegetative growth with increase in cropping density was explained by the reduced interception of light by the plant due to the smaller soil area available per plant and smaller leaf area.

The LA and SLA were also not affected by cropping density, corroborating the results obtained for plant dry matter (Table 1). Watanabe

Table 1. Branch dry matter (BDM), petioles dry matter (PDM), leaf dry matter (LDM), total dry matter (TDM), leaf area (LA), specific leaf area (SLA) and leaf area index (LAI) of mini watermelon plants (hybrid Smile) at the time of fruit harvest according to the training height $(\mathrm{H})$, plant density (D) and their interaction (HxD) [massa seca dos ramos (BDM), massa seca dos pecíolos (PDM), massa seca das folhas (LDM), massa seca total (TDM), área foliar (LA), área foliar específica (SLA) e índice de área foliar (LAI) de plantas de mini melancia (híbrido Smile) no momento da colheita dos frutos em função da altura de condução (H), da densidade de plantas (D) e de sua interação (HxD)]. Piracicaba, ESALQ, 2008.

\begin{tabular}{|c|c|c|c|c|c|c|c|c|c|}
\hline \multirow{2}{*}{ Treatment } & BDM & PDM & & LDM & & TDM & \multirow{2}{*}{$\begin{array}{c}\text { LA } \\
\text { (cm/plant) }\end{array}$} & \multirow{2}{*}{$\begin{array}{l}\text { SLA } \\
(\mathrm{cm} / \mathrm{g})\end{array}$} & \multirow{2}{*}{ LAI } \\
\hline & \multicolumn{6}{|c|}{ (g) } & & & \\
\hline \multicolumn{10}{|c|}{ Training height (H) (m) } \\
\hline 1.7 & $6.17 \mathrm{~b}$ & 1.57 & $\mathrm{~b}$ & 18.47 & $\mathrm{~b}$ & $26.21 \mathrm{~b}$ & $2646.59 \mathrm{a}$ & $142.72 \mathrm{a}$ & $1.04 \mathrm{a}$ \\
\hline 2.2 & $7.71 \mathrm{a}$ & 1.81 & $\mathrm{ab}$ & 21.22 & $\mathrm{a}$ & $30.74 \mathrm{a}$ & $3052.47 \mathrm{a}$ & $143.73 \mathrm{a}$ & $1.22 \mathrm{a}$ \\
\hline 2.7 & $8.23 \mathrm{a}$ & 2.09 & $\mathrm{a}$ & 22.61 & $\mathrm{a}$ & $32.93 \mathrm{a}$ & $3139.84 \mathrm{a}$ & $139.16 \mathrm{a}$ & $1.27 \mathrm{a}$ \\
\hline \multicolumn{10}{|c|}{ Plant density (plants $/ \mathbf{m}^{2}$ ) } \\
\hline 4.76 & $7.22 \mathrm{a}$ & 1.79 & $\mathrm{a}$ & 20.33 & $\mathrm{a}$ & 29.34 a & $3063.56 \mathrm{a}$ & $149.40 \mathrm{a}$ & $1.46 \mathrm{a}$ \\
\hline 3.17 & $7.52 \mathrm{a}$ & 1.86 & $\mathrm{a}$ & 21.20 & $\mathrm{a}$ & $30.57 \mathrm{a}$ & $2829.04 \mathrm{a}$ & $134.34 \mathrm{a}$ & $0.90 \mathrm{~b}$ \\
\hline \multicolumn{10}{|c|}{ Interaction (H x D) } \\
\hline & $\mathrm{ns}$ & ns & & $\mathrm{ns}$ & & ns & ns & ns & ns \\
\hline $\mathrm{CV}(\%)$ & 10.75 & 12.56 & & 7.24 & & 7.55 & 17.51 & 14.16 & 18.49 \\
\hline
\end{tabular}

Means followed by the same letter in the column do not differ by Tukey test at $5 \%$ (médias seguidas pela mesma letra na coluna não diferem entre si pelo teste Tukey a $5 \%$ de probabilidade); ns = not significant by Tukey test at $5 \%$; * = significant by the Tukey test at $5 \%$ (ns $=$ não significativo pelo teste Tukey a 5\%; * significativo pelo teste Tukey a 5\%).

Table 2. Mean fruit matter (MFM), total yield (TY), marketable yield (CY), mean fruit length (MFL), mean fruit diameter (MFD) and fruit shape index (FSI) ) of mini watermelon (hybrid Smile) according to the training height (H), plant density (D) and their interaction (HxD) [massa média dos frutos (MFM), produtividade total (TY), produtividade comercial (CY), comprimento médio dos frutos (MFL), diâmetro médio dos frutos (MFD) e índice de formato do fruto (FSI) de mini melancia (híbrido Smile) em função da altura de condução (H), da densidade de plantas (D) e de sua interação (HxD)). Piracicaba, ESALQ, 2008.

\begin{tabular}{|c|c|c|c|c|c|c|}
\hline Treatment & MFM (kg/fruit) & TY (t/ha) & CY (t/ha) & MFL (cm) & MFD (cm) & FSI \\
\hline \multicolumn{7}{|c|}{ Training height (H) (m) } \\
\hline 1.7 & $1.25 \mathrm{~b}$ & $49.39 \mathrm{c}$ & $46.50 \mathrm{~b}$ & $12.95 \mathrm{~b}$ & $12.91 \mathrm{~b}$ & $1.00 \mathrm{a}$ \\
\hline 2.2 & $1.49 \mathrm{a}$ & $58.80 \mathrm{~b}$ & $54.34 \mathrm{a}$ & $13.67 \mathrm{a}$ & $13.45 \mathrm{ab}$ & $1.02 \mathrm{a}$ \\
\hline 2.7 & $1.59 \mathrm{a}$ & $63.23 \mathrm{a}$ & 57.34 a & $14.03 \mathrm{a}$ & $13.75 \mathrm{a}$ & $1.02 \mathrm{a}$ \\
\hline \multicolumn{7}{|c|}{ Plant density (plants/m²) } \\
\hline 4.76 & $1.42 \mathrm{a}$ & $67.68 \mathrm{a}$ & $61.03 \mathrm{a}$ & $13.52 \mathrm{a}$ & $13.39 \mathrm{a}$ & $1.01 \mathrm{a}$ \\
\hline 3.17 & $1.47 \mathrm{a}$ & $46.60 \mathrm{~b}$ & $44.42 \mathrm{~b}$ & $13.59 \mathrm{a}$ & $13.35 \mathrm{a}$ & $1.02 \mathrm{a}$ \\
\hline \multicolumn{7}{|c|}{ Interaction (H x D) } \\
\hline & $\mathrm{n}$ & * & & " & $\mathrm{n}$ & \\
\hline CV (\%) & 5.62 & 5.91 & 8.91 & 3.12 & 3.69 & 1.56 \\
\hline
\end{tabular}

Means followed by the same letter in the column do not differ by Tukey test at $5 \%$ (médias seguidas pela mesma letra na coluna não diferem entre si pelo teste Tukey a $5 \%$ de probabilidade); ns = not significant by Tukey test at $5 \% ; *=$ significant by the Tukey test at $5 \%$ (ns $=$ não significativo pelo teste Tukey a 5\%; * significativo pelo teste Tukey a 5\%). 
et al. (2003) in vertically cropped mini watermelon reported that between the 90 and $50 \mathrm{~cm}$ spacing, the leaf area values of the plants were statistically similar but differed between the 90 and $30 \mathrm{~cm}$ spacings and the greatest values were obtained at the lowest plant density. According to the authors, the increase in plant density reduced the solar radiation incidence on the interior of the canopy and decreased the individual leaf area on the mid and upper parts of the plant, that was reflected in less solar radiation interception, carbon dioxide absorption by the plant and consequently smaller mean fruit mass.

The SLA, the characteristic that represents the dynamic of carbohydrate accumulation per unit of leaf area (Meziane \& Shipley, 2001) was not influenced by the plant density because the increase in density from 3.75 to 4.76 plants $\mathrm{m}^{-2}$ may not have caused greater competition among the plants for water, light and nutrients. Papadopoulos \& Ormrod (1988) on the other hand, observed that plant adensing (reduction in between-plant spacing from 0.45 to $0.23 \mathrm{~m}$ ) increased the specific leaf area and reduced the solar radiation intercepted by the tomato leaves.

The LAI, however, was higher at the highest cropping density (Table 1). As this characteristic relates the leaf area with the area that the plant occupies soil, reduction in between-plant spacing (adensing) resulted in the increase of this characteristic because the LA was not influenced by the plant density. Similar results were also observed by Duarte et al. (2008) in melon cropped in a protected environment and by Papadopoulos \& Pararajasingham (1997) in tomato. Nederhoff (1984), in an experiment carried out with cucumber in a protected environment and two planting densities (1.42 and 2.14 plants $\mathrm{m}^{-2}$ ) reported at 30 DAT a greater leaf area index and greater solar radiation interception in the less adensed plants. At 48 DAT, however, the leaf area indices of the plants in the two spacings were equal.

Mean mass of the fruit, total and commercial yield, mean length, diameter and shape index - There was interaction between the training height and plant density only for TY and MFL (Table 2).

For the TY, the highest value (76.50 $\mathrm{t} \mathrm{ha}^{-1}$ ) was obtained by the interaction between the $2.7 \mathrm{~m}$ training height and 4.76 plant $\mathrm{m}^{-2}$ density and the greatest number of plants per area increased productivity in all the training heights assessed. At this cropping density, when pruned at $2.2 \mathrm{~m}$, the productivity was $9.9 \%$ lower compared to the highest training height. On the other hand, the $2.7 \mathrm{~m}$ plant training height reduced efficiency because a ladder was needed to carry out this crop treatment.

For the MFL, the highest values, $13.55 \mathrm{ad} 14.33 \mathrm{~cm}$, were obtained at the 4.76 plants $\mathrm{m}^{-2}$ density at the 2.2 and 2.7 $\mathrm{m}$ training heights, respectively.

The plant training height influenced the MFM, CY and MFD, and the highest values were obtained for the MFM and $\mathrm{CY}$ at the 2.2 and $2.7 \mathrm{~m}$ training heights, in agreement with the results obtained for the plant dry matter. For the FMD, the $2.7 \mathrm{~m}$ training height presented a significantly higher value only compared to the $1.7 \mathrm{~m}$ height (Table 2).

The FSI was less influenced by training heights than by plant density (Table 2). Studying melon cropping, Resende \& Costa. (2003) also did not report effect of the number of plants per area on this characteristic. Grangeiro et al. (1999), however, observed rounder melon fruits as plant density increased. Pereira et al. (2003) assessed the effect of tip pruning on two melon hybrids and reported that pruned plants increased the fruit shape index compared to non-

Table 3. Skin thickness (ST), pulp firmness (PF), soluble solid content (SS), titratable acidity (TA), ascorbic acid content (AA) and fruit SS/ TA ratio of mini watermelon (hybrid Smile) according to the training height (H), plant density (D) and their interactions (HxD) (espessura da casca (ST), firmeza da polpa (PF), sólidos solúveis (SS), acidez titulável (TA), ácido ascórbico (AA) e relação entre sólidos solúveis e acidez titulável (SS/TA) da polpa dos frutos de mini melancia (híbrido Smile) em função da altura de condução (H), da densidade de plantas (D) e de suas interações (HxD)). Piracicaba, ESALQ, 2008.

\begin{tabular}{|c|c|c|c|c|c|c|}
\hline Treatment & $\mathrm{ST}(\mathrm{cm})$ & $\operatorname{PF}(\mathbf{N})$ & SS ( ${ }^{\circ}$ Brix) & TA (\%) & $\mathrm{AA}(\mathrm{mg} / 100 \mathrm{~g})$ & SS/TA \\
\hline \multicolumn{7}{|c|}{ H - Training height (m) } \\
\hline 1.7 & $0.59 \mathrm{a}$ & $11.44 \mathrm{a}$ & $10.30 \mathrm{a}$ & 0.14 a & $11.33 \mathrm{a}$ & $76.25 \mathrm{a}$ \\
\hline 2.2 & $0.62 \mathrm{a}$ & $10.64 \mathrm{a}$ & $10.23 \mathrm{a}$ & $0.13 \mathrm{a}$ & $11.04 \mathrm{a}$ & 78.64 a \\
\hline 2.7 & $0.55 \mathrm{a}$ & $9.84 \mathrm{a}$ & $10.41 \mathrm{a}$ & $0.13 \mathrm{a}$ & $12.03 \mathrm{a}$ & $81.26 \mathrm{a}$ \\
\hline \multicolumn{7}{|c|}{ Plant density (plants/m²) } \\
\hline 4.76 & 0.53 a & $10.62 \mathrm{a}$ & $10.51 \mathrm{a}$ & 0.14 a & $12.00 \mathrm{a}$ & 75.50 a \\
\hline 3.17 & $0.65 \mathrm{a}$ & $10.66 \mathrm{a}$ & $10.13 \mathrm{~b}$ & $0.13 \mathrm{~b}$ & $10.93 \mathrm{~b}$ & $81.88 \mathrm{a}$ \\
\hline \multicolumn{7}{|c|}{ Interaction (H x D) } \\
\hline & ns & ns & ns & ns & ns & $*$ \\
\hline $\mathrm{CV}(\%)$ & 26.93 & 17.09 & 3.50 & 10.05 & 8.25 & 9.56 \\
\hline
\end{tabular}

Means followed by the same letter in the column do not differ by Tukey test at $5 \%$ (médias seguidas pela mesma letra na coluna não diferem entre si pelo teste Tukey a $5 \%$ de probabilidade); ns = not significant by Tukey test at $5 \%$; $=$ significant by the Tukey test at $5 \%$ (ns $=$ não significativo pelo teste Tukey a $5 \% ; *$ = significativo a pelo teste Tukey a $5 \%$ ). 
pruned plants, that is, the fruits became longer.

However, this result was only significant for the "Hy Mark" hybrid indicating that the fruit shape was also influenced by genetic factors. Furthermore, the fruit shape index can be affected by the number of fruit and their position on the plant, as reported by Sebrae Júnior et al. (2003) in melon cropping in a protected environment.

The plant density did not influence the MFM and MFD, corroborating the results obtained for dry matter of the different plant parts, LA and SLA (Table 2). Nunes et al. (2008) did not observe influence of plant density (10 and 15 plants $\mathrm{m}^{-2}$ ) on the mean mass of 'pele de sapo' melon fruits. However, Watanabe et al. (2003) and Goreta et al. (2005) in watermelon and Gualberto et al. (2001), Resende \& Costa (2003), Silva et al. (2003) and Ban et al. (2006) in melon reported that increased plant density reduced the mean fruit mass. Kultur et al. (2001) observed in melon that the reduction in between-plant spacing from 70 to $35 \mathrm{~cm}$ ( $50 \%$ increase in the number of plants per area) reduced the fruit mass by $9.57 \%$ but raised productivity by $45.11 \%$.

According to Watanabe et al. (2003), the cropping density of mini watermelon trained in the vertical system influenced leaf area and solar radiation incidence on the plant that subsequently interfered in the photosynthesis efficiency and fruit mass.

The CY was influenced by plant density. This characteristic, when compared to the TY, decreased by $4.6 \%$ at the lowest plant density and $9.8 \%$ at the highest. However, in spite of the increase in the number of noncommercial fruit, the CY at the highest cropping density was $37.4 \%$ greater compared to the lowest density.

Pulp firmness, skin thickness, soluble solids content, ascorbic acid content, titratable acidity and SS/TA ratio of the fruit - There was significant interaction between training height and plant density only for the SS/TA ratio (Table 3 ). The highest values of this characteristic were obtained at the lowest cropping density (3.17 plants $\mathrm{m}^{-2}$ ) when the plants were trained at $2.2 \mathrm{~m}$ height. At the greatest cropping density, there was no difference among the training heights for the SS ratio.

The plant training height did not influence the ST, PF, SS, TA and the AA of the fruit pulp (Table 3 ). The fruits from the plants at all the training heights presented values adequate for all the qualitative characteristics, and the fruit mean soluble solid content was greater than $10^{\circ}$ Brix, considered, according to Almeida (2006), the limit value for harvesting good-quality fruits.

Regarding the plant density, the variation in the number of plants per area did not significantly affect the fruit ST and PF and presented general means of $0.58 \mathrm{~cm}$ and $10.64 \mathrm{~N}$, respectively. For the fruit pulp SS, TA and AA (Table 3 ) however the highest values were obtained at the greatest cropping density (4.76 plants $\mathrm{m}^{-2}$ ).

It is pointed out that the increases resulting from the increase in cropping density in SS, TA and AA was small, $0.379{ }^{\circ}$ Brix, $0.01 \%$ and $1.07 \mathrm{mg} 100$ $\mathrm{g}^{-1}$, respectively. For Mendlinger (1994), the increase in density from 2.0 to 8.0 plants $\mathrm{m}^{-2}$ decreased the soluble solid content from 15.8 to $15.1^{\circ}$ Brix and raised acidity from 12.63 to $13.73 \mathrm{meq}$ $\mathrm{g}^{-1}$. On the other hand, Resende \& Costa (2003) and Nunes et al. (2008) reported that increases in plant density from 0.83 to 2.77 plants $\mathrm{m}^{-2}$ in yellow melon, and from 1.0 to 1.5 plants $\mathrm{m}^{-2}$ in 'pele de sapo' melon and from 0.41 to 1.66 plants $\mathrm{m}^{-2}$ in watermelon, respectively, did not affect the fruit soluble solids content.

We concluded that the $2 \mathrm{~m}$ training height of the main stem resulted in high CY and fruit quality and was also the least expensive training height system compared to the 2.7 training height system that also gave similar results. Regarding plant density, the best option was 4.7 plants $\mathrm{m}^{-2}$ because, compared to the lower density, it raised the CY by $37.4 \%$ without significantly reducing the MFM. At this cropping density, the fruit quality met the consumer standard.

\section{REFERENCES}

ALMEIDA D. 2006. Manual de culturas horticolas. Lisboa: Ed. Presença, vol. 2. 325 p.
BAN D; GORETA S; BOROSIC J. 2006. Plant spacing and cultivar affect melon growth and yield components. Scientia Horticulturae 109: 238-243.

CARVALHO CRL; MANTOVANI DMB; CARVALHO PRN; MORAES RMM. 1990. Análises químicas de alimentos: manual técnico. Campinas: Instituto de Tecnologia de Alimentos. 121 p.

CHITARRA MIF; CHITARRA AB. 2005. Póscolheita de frutas e hortaliças: fisiologia e manuseio. Lavras: UFLA. 785 p.

DUARTE TS; PEIL RMN; MONTEZANO EM. 2008. Crescimento de frutos do meloeiro sob diferentes relações fonte:dreno. Horticultura Brasileira 26: 342-347.

DUARTE TS; PEIL RMN. 2010. Relações fonte:dreno e crescimento vegetativo do meloeiro. Horticultura Brasileira 28: 271-276.

FAO. 2012. Agricultural production, primary crops. 2010. Disponível em $<$ http://www.fao. org>. Acesso em: 10 de maio de 2012.

GORETA S; PERICA S; DUMICIC LB; ZANIC K. 2005. Growth and yield of watermelon on polyethylene mulch with different spacings and nitrogen rates. Hortscience 40: 366-369.

GRANGEIRO LC; PEDROSA JF; BEZERRA NETO F; NEGREIROS MZ. 1999. Qualidade de híbridos de melão em diferentes densidades de plantio. Horticultura Brasileira 17: 110113.

GUALBERTO R; RESENDE FV; LOSASSO PHL. 2001. Produtividade e qualidade do melão rendilhado em ambiente protegido, em função do espaçamento e sistema de condução. Horticultura Brasileira 19: 240-243.

HEUVELINK E. 1995. Effect of plant density on biomass allocation to the fruit and tomato (Lycopersicon esculetum Mill.). Scientia Horticulturae 64: 193-201.

KULTUR F; HARRISON HC; STAUB JE. 2001. Spacing and genotype affect fruit sugar concentration, yield, and fruit size of muskmelon. Hortscience 36: 274-278.

MARTINS SR; FERNANDES HS; ASSIS FN; MENDEZ MEG. 1999. Caracterização climática e manejo de ambientes protegidos: a experiência brasileira. Informe Agropecuário 20: 15-23.

MAROUELLI WA. 2008. Tensiômetro para o controle de irrigação em hortaliças. Embrapa: Brasília, Circular Técnico, n.57. 15p.

MENDLINGER S. 1994. Effect of increasing plant density and salinity on yield and fruit quality in muskmelon. Scientia Horticulturae 57: 41-49.

MEZIANE D; SHIPLEY B. 2001. Direct and indirect relationships between specific leaf area, leaf nitrogen and leaf gas exchange. Effects of irradiance and nutrient supply. Annals of Botany 88: 915-927.

NEDERHOFF EM. 1984. Light interception of a cucumber crop at different stages of growth. Acta Horticulturae 148: 525-534.

NUNES GHS; PEREIRA EWL; SALES JUNIOR R; BEZERRA NETO F; OLIVEIRA KC; MESQUITA LX. 2008. Produtividade e qualidade de frutos de melão pele-de-sapo em duas densidades de plantio. Horticultura 
Brasileira 26: 236-239.

PAPADOPOULOS AP. 1994. Growing greenhouse seedless cucumbers in soil and in soilless media. Ottawa: Agriculture and Agri-Food Canada. 126 p.

PAPADOPOULOS AP; PARARAJASINGHAM S. 1997. The influence of plant spacing on light interception and use in greenhouse tomato (Lycopersicon esculentum Mill.): A review. Scientia Horticulturae 69: 1-29.

PAPADOPOULOS AP; ORMROD DP. 1988. Plant spacing effects on photosynthesis and transpiration of the greenhouse tomato. Canadian Journal of Plant Science 68: 12091218.

PEIL RM; LÓPEZ-GÁLVEZ J. 2002. Fruit growth and biomass allocation to the fruit in cucumber: effect of plant density and arrangement. Acta Horticulturae 588: 75-80.

PEREIRA FHF; NOGUEIRA ICC; PEDROSA
JF; NEGREIROS MZ; BEZERRA NETO F. 2003. Poda da haste principal e densidade de cultivo sobre a produção e qualidade de frutos em híbridos de melão. Horticultura Brasileira 21: 191-196.

QUEIROGA RCF; PUIATTI M; FONTES PCR; CECON PR. 2008. Produtividade e qualidade de frutos de meloeiro variando o número de frutos e de folhas por planta. Horticultura Brasileira 26: 209-215.

RAMOS ARP; DIAS RCS; ARAGÃO CA. 2009. Densidades de plantio na produtividade e qualidade de frutos de melancia. Horticultura Brasileira 27: 560-564.

RESENDE GM; COSTA ND. 2003. Produção e qualidade do melão em diferentes densidades de plantio. Horticultura Brasileira 21: 690694.

SANDERS DC; CURE JD; SCHULTHEIS JR. 1999. Yield response of watermelon to planting density, planting pattern, and polyethylene mulch. HortScience 34: 1221-1223.

SEABRA JÚNIOR S; PANTANO SC; HIDALGO AH; RANGEL MG; CARDOSO AII. 2003. Avaliação do número e posição de frutos de melancia produzidos em ambiente protegido. Horticultura Brasileira 21: 708-711.

SILVA PSL; FONSECA JR; MOTA JCA; SILVA J. 2003. Densidade de plantio e rendimento de frutos do meloeiro (Cucumis melo L.). Revista Brasileira de Fruticultura 25: 245-247.

WATANABE S; NAKANO Y; OKANO K. 2003. Effect of planting density on fruit size, light-interception and photosynthetic activity of vertically trained watermelon (Citrullus lanatus (Thunb.) Matsum. et Nakai) plants. Journal of Japaneses Society for the Horticultural Science 72: 497-503.

WILLEY RW; HEATH SB. 1969. The quantitative relationships between plant population and crop yield. Advances in Agronomy 21: 281321. 